\title{
Erratum to: Genetic characterization of border disease virus (BDV) isolates from small ruminants in Italy
}

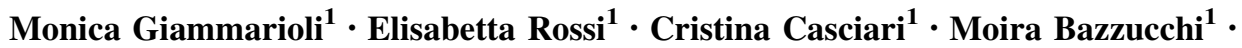
Claudia Torresi ${ }^{1} \cdot$ Gian Mario De Mia ${ }^{1}$

Published online: 20 March 2015

(C) Springer Science+Business Media New York 2015

\section{Erratum to: Virus Genes}

DOI 10.1007/s11262-014-1165-6

The name of the fifth author was incorrectly published in the original publication. The correct author name should have been Claudia Torresi.

The online version of the original article can be found under doi: 10.1007/s11262-014-1165-6.

\section{Gian Mario De Mia} gm.demia@izsum.it

1 Istituto Zooprofilattico Sperimentale dell'Umbria e delle Marche, Via Salvemini 1, 06126 Perugia, Italy 